\title{
Methodological design of a performance measurement system for the colombian shipyard supply chain
}

Diseño metodológico de un sistema de medición del desempeño para la cadena de suministros de astilleros en Colombia

\begin{abstract}
The design of a performance measurement system for the Colombian shipyard supply chain is shown in this paper, using a model that integrates the principles of the Balanced Scorecard with the fuzzy sets theory to treat uncertainty associated with selected logistics indicators, enabling better supply chain management.
\end{abstract}

Key words: Indicator, performance measurement, supply chain, fuzzy logic, Balanced Scorecard, shipyard.

\section{Resumen}

El presente artículo muestra el diseño de un sistema de medición del desempeño para la cadena de suministros de los astilleros colombianos, usando un modelo que integra los principios del Balanced Scorecard con la teoría de conjuntos difusos para el tratamiento de la incertidumbre asociada a los indicadores logísticos seleccionados, posibilitando mejor gestión de dicha cadena.

Palabras claves: Indicadores, medición del desempeño, cadena de suministros, lógica difusa, Balanced Scorecard, astilleros.

\footnotetext{
${ }^{1}$ Universidad Nacional de Colombia, Facultad de Minas, Escuela de Ingeniería de la Organización. Medellín, Colombia. e-mail: jmcogollof@unal.edu.co

${ }^{2}$ Universidad Nacional de Colombia, Facultad de Minas, Escuela de Ingeniería de la Organización. Medellín, Colombia. e-mail: mdarango@unal.edu.co

${ }^{3}$ COTECMAR. Dirección Financiera y Administrativa. Cartagena, Colombia. e-mail: jigomez@cotecmar.com

${ }^{4}$ COTECMAR. División de Gestión Logística. Cartagena, Colombia. e-mail: spuello@cotecmar.com
} 


\section{Introduction}

Modern global environment changed the focus of business rivalry, from a competition between individual organizations to supply chain rivalry. A supply chain is a network consisting of suppliers, manufacturers, warehouses and wholesale distributors, and retailers who - through coordinated plans and activities - develop products that will increase their added value as they flow up the final consumer to meet their needs and requirements. Regardless of the approach, product type or size of operations, supply chain performance is what will determine its ability to generate customer value. Therefore, organizational management requires developing performance measurement systems adapted to the presence of various companies, which is considered one of the most impacting tools on supply chain management (Ballou et al., 2000; Lancioni, 2000).

Generally, performance measurement has had an intra-organizational approach and although discussions and frameworks appear in the literature about performance measures in supply chains, there is a lack of empirical analysis and case studies on metrics and performance measurement systems within the context of supply chains, more so in the case of Colombia. That is why this paper aims to develop a methodology for designing a performance measurement system for the supply chain in uncertainty environments, in a case applied to the Colombian design, construction, maintenance, and repair of ships and the naval industry. A model integrating the principles of the Balanced Scorecard (BSC) with the fuzzy-set theory to deal with the uncertainty associated with the selected logistics indicators, enabling better supply chain management is proposed.

Fuzzy logic application in performance measurement has had some developments in recent years, especially by various researchers in the Asia-Pacific region. The most relevant works were profusely published from 2000, approximately, starting with Lau et al., (2002) who developed a methodology to analyze and monitor supplier performance in a supply chain based on product quality and delivery time criteria. Ling et al., (2006) developed an indicator to evaluate agility in supply chains by using fuzzy logic to deal with ambiguity because they believe that this is a useful tool for making decisions in which the phenomena are vague and imprecise. The fuzzy indicator focuses on linguistic approach application and fuzzy arithmetic to synthesize fuzzy numbers to obtain the agility index of manufacturing operations.

Silva et al., (2007) used fuzzy weighted aggregation to formulate logistics systems optimization problems, which can be extended to different optimization method types like genetic algorithms or ant colonies. Another important work was done by Kanda and Deshmukh (2007), who applied the fuzzy logic approach combined with AHP in assessing the coordination level among supply chain members. Similarly, Ohdar and Kumar (2004) developed a fuzzy methodology based on genetic algorithms for supplier performance evaluation.

This article is structured as follows: first, a description of shipyard supply chains and a conceptual review of performance measurement in supply chains are made. Then, we present the evolution of research on the subject through the different approaches that have had scientific production on the issue. Thereafter, we establish the proposed methodology, the theoretical aspects, and the application form. Lastly, we show the results obtained by applying said methodology and their analysis is made along with the conclusions.

\section{Shipyard Supply Chains}

Implementing supply chain management initiatives requires classifying them according to the specific market characteristics and the life cycle of products, industry type, as well as degree of product customization, business strategy, and organizational skills.

A shipbuilder is basically an assembly plant on structural steel. However, it has an important subsidiary component of manufacturing activities for cutting, bending, and shaping steel plates and pipes according to the ship's design specifications. 
Incorporating advanced techniques of production planning has allowed the construction of boats from subunits or modules with pre-integrated facilities and systems, which are combined to form the vessel. A repair shipyard performs various activities, which require high flexibility and adaptability to customer needs.

Naval, maritime, or fluvial construction or repair projects are divided into a number of subprojects conducted generally by contractors, which must deliver a ship's operating area. This must consider operations, shipyard supply chain performance engineer-to-order (ETO) and made-to-order (MTO) operations. In ETO chains, the critical point is the design stage so that each order (ship building or repair in the shipyard) has a particular design stage (Gosling and Naim, 2009) largely determined by the customer, and develops simultaneous multiple products with different specifications and stages of the manufacturing process (Abdul and Nabi, 2003). In MTO chains, the critical point lies in the manufacture and purchase of raw materials and inputs (Olhager, 2003) and reducing delivery time is not a fundamental purpose because of the disparity of these depending on the intervention need.
Delivery time of supplies and spare parts is a critical point in repair projects because of their short duration (from seven to fifteen days or so) and there is high demand for deadline compliance from the customer. Out-of-service ship fixed costs are very high (crew salaries, ship affreightment), days of shipyard cost, and lost transport service billing are loss factors for ship owners. It is also quite common to make adjustments to initial materials and supplies requisition as requirements vary during development of repair activities.

Based on relationships and materials flow between facilities, in general, shipyard supply chains may be convergent (Fig. 1), given that each node or facility has more than one successor, but may have any number of predecessors (Beamon and Chen, 2001). Usually, shipyards do not have a commercial distribution system of repaired or built vessels; the product is delivered in the shipyard to ship owners who carry it to the final destination. The shipyard may assume a dominant position because it is the backbone of the supply chain, by determining the operations and performance, making a network organization in an Extended Enterprise (CapóVicedo et al., 2007; Lehtinen and Ahola, 2010).

Fig. 1. A schematic representation of shipyard supply chain structure

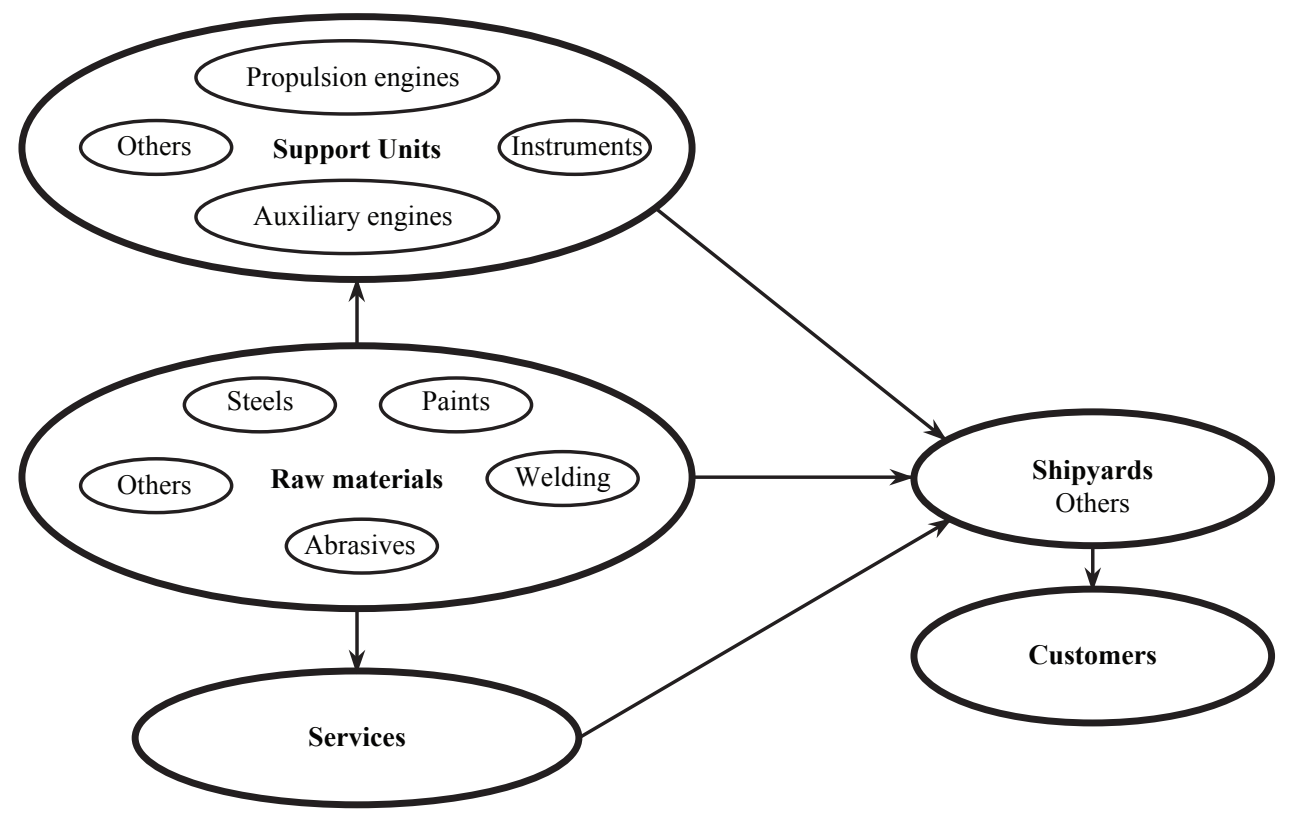




\section{Logistics Performance Indicators}

Organizations may have many performance indicators that are often difficult to measure and monitor. Therefore, selecting a subset of indicators called Key Performance Indicators (KPI), which are representative and may be measured with relative ease and reasonable cost is recommended (Hausman, 2005). The KPIs of the organization (or supply chain, in this case) should be carefully selected considering strategic planning, available resources (human, financial, technological, etc.), and market conditions (Gunasekaran et al., 2001).

Normally, performance indicators are classified as qualitative and quantitative. Qualitative performance indicators are those for which there is no direct numerical measurement, although some aspects can be quantified. The following indicators, among others, fall within this category (Chan et al., 2003):

- Customer satisfaction: degree to which customers are satisfied with product or service received.

- Flexibility: ability of the supply chain to respond to random fluctuations in demand patterns.

- Integration of materials and information flows: degree to which all functions in the supply chain may exchange information and materials without drawbacks.

- Effective risk management: the extent to which the effects of risks are minimied.

- Supplier performance: measuring the performance of raw material suppliers in terms of quality and delivery time.

Quantitative performance indicators may be directly measured in numerical form. They are also sub-divided into four classes (Nyhuis, 2007):

- Cost and financial indicators: cost of entire supply chain, sales levels, profits, inventory investment, return on investment.

- Customer response indicators: compliance rate, percentage of late deliveries, customer response time, and order time.

- Performance indicators: capacity utilization, use of resources.

- Quality indicators: measure the effectiveness of the implementation of activities or processes, providing results on the number of errors, as well as perfect and error-free deliveries.

\section{BSC and Performance Measurement}

Monitoring, measurement, analysis, and improvement of corporate strategy require using appropriate tools that reflect the reality in the deployment of that strategy, both internally and in interaction with the other members of the supply chain. Various methods to evaluate supply chain performance and organizations have been proposed over the years; however, most do not have a balanced approach and focus on financial indicators, $b$ they are not suitable for new generations of applications in supply chain management.

The need for performance measurement tools at different levels of decision making and a balanced approach led Kaplan and Norton (1992) to propose the BSC as a means to evaluate the performance of an organization from four different perspectives: customer, financial, internal processes, and learning and growth.

Originally, te BSC concept was essentially a measuring tool. It then evolved into a comprehensive strategic implementation tool. Today, BSC is a performance management system that aligns and focuses organization efforts and resources, using performance indicators to drive strategies and create long-term value. BSC application in supply chain management is structurally similar to the traditional model of corporate management; the difference is that the indicators must be designed to fully evaluate supply chain performance and not only intra-organizational level.

\section{Fuzzy Logic and Performance Measurement}

Information lack and information excess create uncertainty and imprecision. Due to growing availability of qualitative information for performance measurement is more practical 
and easy to measure supply chain performance in linguistic terms, including vagueness concept (Wang, 2010). Therefore, performance measurement becomes an important area for fuzzy set theory application incorporating quantitative and qualitative measurements (Ammar and Wright, 2000).

Fuzzy logic is a multivariate logic allowing a more practical way to address problems as they occur in the real world. It originates from the fuzzy sets theory proposed by Zadeh (1975), which represents a generalization of the classical sets theory and applies to concepts that can take any truth value in a set of values ranging between absolute truth and total lie. The fuzzy sets foundation is the fact that the building blocks of human reasoning are not numbers but linguistic labels; thereby, fuzzy logic emulates this feature and uses approximate data to find precise solutions.

The fuzzy-set theory strength lies in its ability to provide an alternative framework to modeling imprecision. This allows looking at the vague and possibility concepts separated from the random or probabilistic uncertainty (Klir and Yuan, 1995). A fuzzy set is defined by a function that varies between 0 (false) and 1 (true), which assigns the membership degree of each element in a set. The shape of the membership function can be linear (triangular or trapezoidal) or nonlinear (Gaussian, generalized Bell, sigmoid, gamma, etc.,) depending on the nature of the system studied (Kaufmann and Gil, 1993). The membership degree represents the degree to which expert opinion places an item in the set. An element can belong to more than one set with different membership degrees, allowing gradual transition between adjacent sets.

\section{Fuzzy BSC Model to Measure Shipyard Supply Chain Performance}

In the BSC traditional formulation, the variables are represented by using numerical values and ignoring the fact that, in practice, they are affected by imprecision and vagueness and need to incorporate, in many cases, qualitative variables in measuring performance, hindering mathematical modeling to obtain a specific result to facilitate decision making. To solve this problem and incorporate uncertainty and approximate reasoning in real applications to measure performance in the supply chain studied, a fuzzy logic model is integrated onto the BSC methodology.

The proposed Fuzzy BSC Model has two major components: a knowledge-based and fuzzy processor (Fig. 2). The selection of indicators requires a preliminary stage of literature review and/or consultation with experts on BSC implementation in measuring supply-chain performance and appropriate fuzzy logic models, followed by a stage of contextualization and benchmarking with industry to determine acceptance levels that will serve as input to construct the fuzzy sets and associated membership function with each indicator and then construct the fuzzy rule base necessary for fuzzy processor.

The selected indicators and membership function values are combined in each perspective by using the fuzzy rule base, which contains the set of IF-THEN rules developed from experience and knowledge of a Performance Measurement Team, consisting of personnel from all areas of the organization with training and experience in the field. The Fuzzy Inference System combines the performance levels of the indicators obtained as output of each rule as a single fuzzy output. Defuzzification of the output obtains a crisp number as supply-chain performance indicator.

\section{Fuzzy BSC Model Application}

The application of the Fuzzy BSC Model was carried out by following the steps: selection of indicators, definition of fuzzy inference method, design of the fuzzy rules system, and defuzzification.

\section{Selection of indicators}

The selection of appropriate performance indicators to measure shipyard supply-chain performance is a critical step in the Fuzzy BSC Model application due to the complexity of business 
Fig. 2 . Fuzzy BSC Model for supply-chain performance measurement

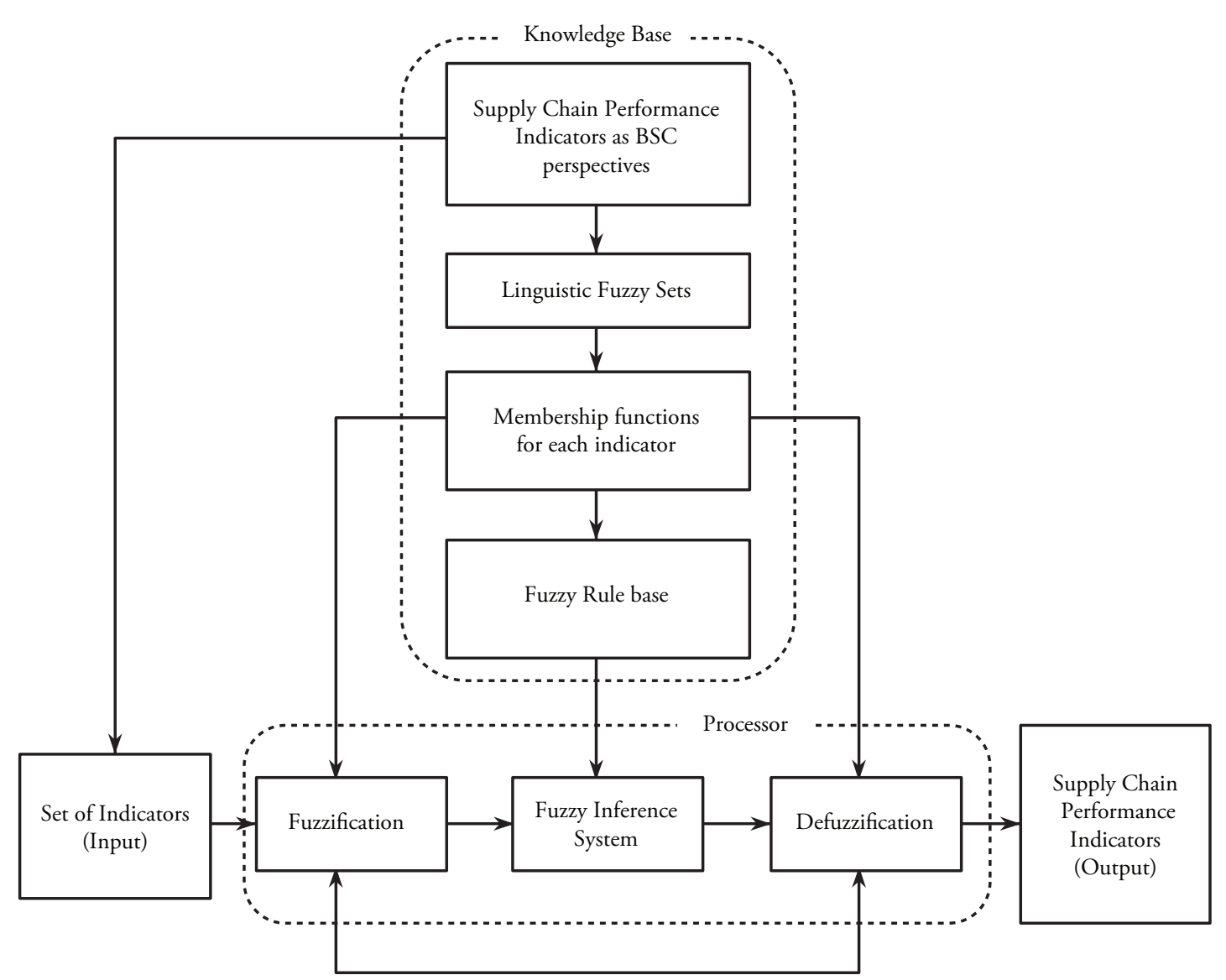

in this industry: large number of players (many suppliers, Classification Societies, Salvage or Tug Companies, contractors, government entities, etc.) that influence the development of operations, unique design phases, and different manufacturing and delivery times for each product. The indicators selected for the Fuzzy BSC Model to measure the performance of the shipyard supply chain studied are shown in Table 1.

\section{Fuzzy Inference Method}

A fuzzy inference method allows deriving conclusions (fuzzy value) from IF-THEN rules set and input-values set to the system by applying the composition ratios. The two most important methods of inference are the Mandani-type model, the most commonly used and introduced by Mandani and Assilian (1975), and the TakagiSugeno-Kang (TSK) model proposed by Sugeno and Takagi (1985).
The main difference between these two methods is the type of consequence in fuzzy rules. While the Mandani systems use fuzzy sets as a consequence of the rule, the TSK systems employ linear functions of input variables. In this paper, the Mandanitype inference system is used because its outputs are continuous values, while the TSK systems are discrete data.

\section{Fuzzy Inference Rules}

The definition of the rules is the most important stage in the design of the Fuzzy BSC Model as embodying the opinion of experts and/or analysis of historical information. This model contains four rule sets for the perspectives and one rule set for global supply-chain performance indicator. The construction of the rules system was made by developing a conclusions matrix by considering all possible combinations of inputs and assigning a conclusion to each. 
Table 1 . Set of indicators to measure shipyard supply-chain performance by using the Fuzzy BSC Model

\begin{tabular}{|c|c|c|c|}
\hline Perspective & No & Indicators & Units \\
\hline \multirow{3}{*}{ Customer } & 1 & New customer sales & Percentage \\
\hline & 2 & Customer satisfaction & Percentage \\
\hline & 3 & Sales Compliance & Percentage \\
\hline \multirow{3}{*}{ Financial } & 4 & Operating margin & Percentage \\
\hline & 5 & Fixed-Asset Turnover & Times \\
\hline & 6 & EVA & $\$$ \\
\hline \multirow{4}{*}{$\begin{array}{l}\text { Internal } \\
\text { Process }\end{array}$} & 7 & Cost of warehouse space & $\$ /$ space \\
\hline & 8 & Order rejection rate & Percentage \\
\hline & 9 & Inventory turnover & Times \\
\hline & 10 & Main assets turnover & $\begin{array}{l}\text { CGT/ } \\
\left(\mathrm{m}^{2} . \mathrm{m} . \text { Ton }\right)\end{array}$ \\
\hline \multirow{3}{*}{$\begin{array}{l}\text { Learning and } \\
\text { Growth }\end{array}$} & 11 & Employee turnover & Percentage \\
\hline & 12 & $\mathrm{R} \& \mathrm{D} /$ Sales investment & Percentage \\
\hline & 13 & Corporate Governance Compliance & Percentage \\
\hline
\end{tabular}

Customer perspective, for example, is evaluated in three input variables (new customers sales, customer satisfaction and sales compliance), which have three fuzzy categories (low, medium and high); therefore, there are $33=27$ possible combinations in the matrix of definition of fuzzy rules (Table 2). Values in the cells represent the consequence of describing each combination and correspond to the linguistic categories or labels of fuzzy subsets of the output variable, and "L" corresponds to low, "ML" is medium-low, "S" is standard, "MH" is medium to high, and " $\mathrm{H}$ " is high. These labels apply to the definition of rules in the remaining four rule sets.

Any cell in Table 2 may be expressed as a rule. For example, the shaded cell corresponds to the following rule: IF sales compliance is medium and customer satisfaction is low and new customers sales is low, THEN customer perspective is low.

Table 2 . Fuzzy rules matrix of customer perspective

\begin{tabular}{|c|c|c|c|c|c|c|c|c|c|c|c|}
\hline \multicolumn{12}{|c|}{ Sales Compliance } \\
\hline \multicolumn{4}{|c|}{ Low } & \multicolumn{4}{|c|}{ Medium } & \multicolumn{4}{|c|}{ High } \\
\hline \multirow[t]{2}{*}{$\begin{array}{c}\text { New } \\
\text { costumer } \\
\text { sales }\end{array}$} & \multicolumn{3}{|c|}{$\begin{array}{l}\text { Costumer } \\
\text { Satisfaction }\end{array}$} & \multirow[t]{2}{*}{$\begin{array}{c}\text { New } \\
\text { costumer } \\
\text { sales }\end{array}$} & \multicolumn{3}{|c|}{$\begin{array}{l}\text { Costumer } \\
\text { Satisfaction }\end{array}$} & \multirow[t]{2}{*}{$\begin{array}{c}\text { New } \\
\text { costumer } \\
\text { sales }\end{array}$} & \multicolumn{3}{|c|}{$\begin{array}{l}\text { Costumer } \\
\text { Satisfaction }\end{array}$} \\
\hline & Low & Medium & High & & Low & Medium & High & & Low & Medium & High \\
\hline Low & $\mathrm{L}$ & $\mathrm{L}$ & $\mathrm{L}$ & Low & $\mathrm{L}$ & ML & ML & Low & S & S & $\mathrm{MH}$ \\
\hline Medium & $\mathrm{L}$ & $\mathrm{L}$ & $\mathrm{L}$ & Medium & ML & S & S & Medium & S & MH & $\mathrm{H}$ \\
\hline High & $\mathrm{L}$ & $\mathrm{L}$ & ML & High & $\mathrm{MH}$ & $\mathrm{MH}$ & $\mathrm{MH}$ & High & $\mathrm{MH}$ & $\mathrm{H}$ & $\mathrm{H}$ \\
\hline
\end{tabular}




\section{Defuzzification}

The result of the inference process is a set with a fuzzy distribution as response. However, because generally specific responses are used to facilitate decision making, it is necessary to remove the fuzziness to obtain a crisp number. The literature describes various methods to eliminate fuzziness as the center of the area, bisecting the area, smaller than maximum or larger than maximum (Jang et al., 1997). The appropriate method depends on its degree of adjustment to considerations and constraints of the application.

The center-of-area method is one of the most commonly used and was used in this study because of its continuity and because it calculates the overlap area only once, unlike other methods. The specific value of the performance indicators for each perspective and global supply-chain performance indicator were generated by finding the center of gravity of the membership function of respective fuzzy outputs. Analytical development and calculations were performed by using the Matlab(C) Fuzzy Toolbox.

\section{Global Supply-Chain Performance Indicator}

The computational results of applying the Fuzzy BSC Model for shipyard supply-chain performance measurement are shown in Figure 3. The BSC perspective indicator results (Customer $=75 \%$, Financial $=85 \%$, Internal process $=78 \%$, and Learning and Growth $=92 \%$ ) and global shipyard supply-chain performance indicator $(75.9 \%)$ may be interpreted as the degree to which the supply chain achieves the goals and objectives of supply chain management within each perspective and globally.

\section{Conclusions}

Performance measurement is an essential element in planning, control, and decision making of

Fig. 3. Computational results of shipyard supply chain performance measurement using Fuzzy BSC Model

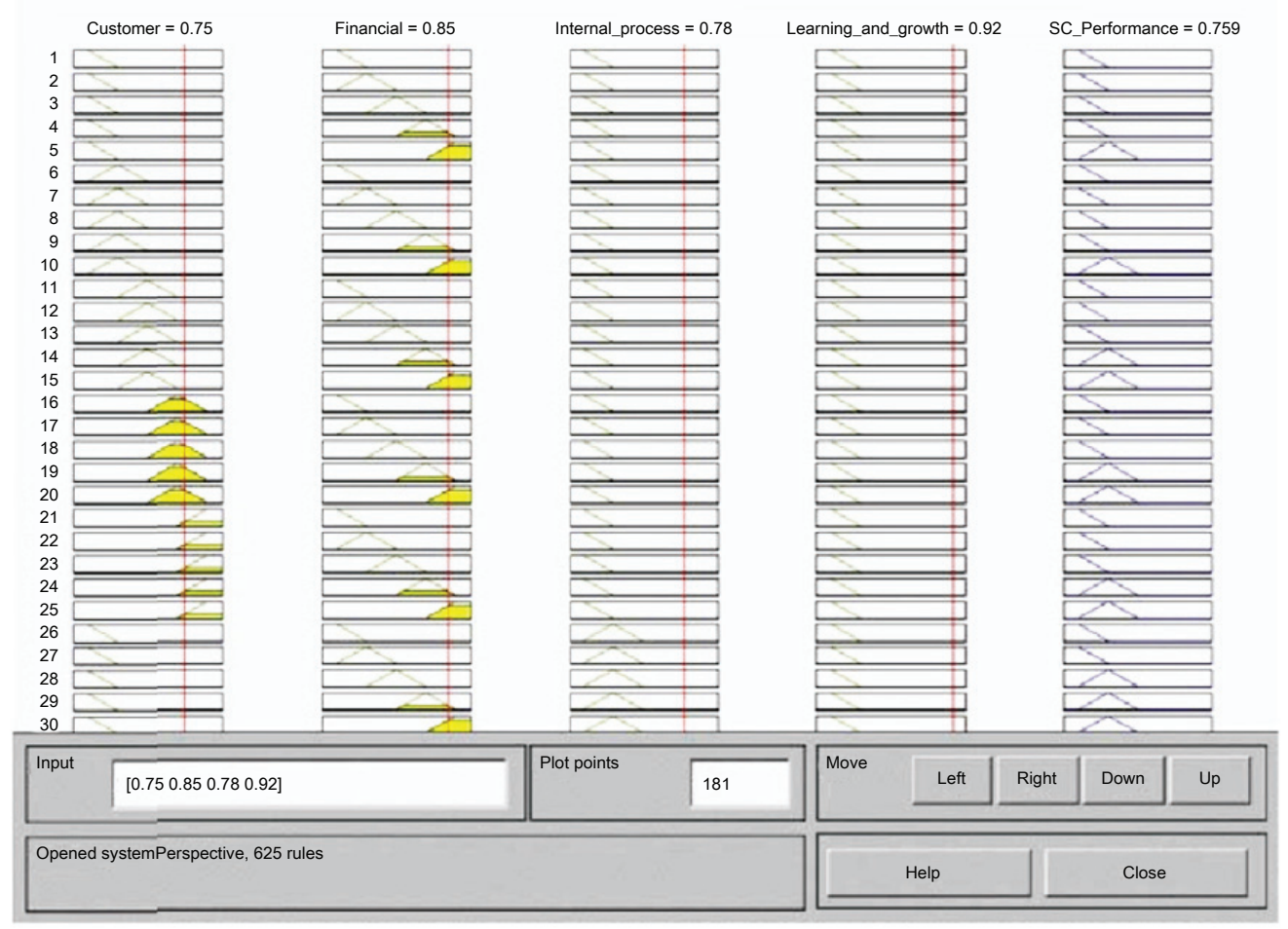


supply and chain management. It is necessary to move towards performance measurements systems that consider interaction with all the links in the chain and go beyond the internal focus that still prevails in most organizations.

Fuzzy logic provides a new approach to modeling the uncertainty that characterizes supply chain management. Furthermore, it is considered easier to apply and adapt compared to conventional approaches, especially when there is a large number of input data.

Modeling indicators using fuzzy logic should not be approached as a way to compare results with classical logic because the former is an extension of the second and there should be no contradiction between the results with either approach. The difference is that fuzzy logic allows for an extension of the information obtained and increased ability to represent vague or uncertain phenomena.

The application of the proposed Fuzzy BSC Model allowed obtaining specific numerical values like BSC perspective indicators and global performance indicators in the supply chain studied. This model has a systematic structure that allows easy adaptation to other supply chain types or other business management problems.

\section{References}

ABDUL, A. and NABI, M. The need for a new product development framework for engineerto-order products. European Journal of Innovation Management, 6 (3): 182-196, 2003.

AMMAR, S. and WRIGHT, R. Applying fuzzyset theory to performance evaluation. SocioEconomic Planning Sciences, 34: 285 -302, 2000 .

BALLOU, R., GILBERT, S. and MUKHERJEE, A. New Managerial Challenges from Supply Chain Opportunities. Industrial Marketing Management, 29: 7-18, 2000.
BEAMON, B. and CHEN, V. Performance analysis of conjoined supply chains. International Journal of Production Research, 39 (14): 31953218, 2001.

CAPÓ-VICEDO, J., TOMÁS-MIQUEL, J. and EXPÓSITO-LANGA, M. La gestión del conocimiento en la cadena de suministro: Análisis de la influencia del contexto organizativo. Información Tecnológica, 18(1): 127-135, 2007.

GOSLING, J. and NAIM, M. Engineer-to-order supply chain management: a literature review and research agenda. International Journal of Production Economics, 122: 741-754, 2009.

KANDA, A. and DESHMUKH, S.G. Coordination in supply chains: an evaluation using fuzzy logic. Production Planning o Control, 18 (5): 420-435, 2007.

KAUFMANN, A. and GIL, J. Introducción de la teoría de los subconjuntos borrosos a la gestión de las empresas. 3 ed. Santiago de Compostela: Milladoiro, 1993. 252 P.

KLIR, G. and YUAN, B. Fuzzy Sets and Fuzzy Logic: Theory and Application. New Jersey: Prentice Hall, 1995.

LANCIONI, R. New Developments in Supply Chain Management for the Millennium. Industrial Marketing Management, 29: 1-6, 2000 .

LAU, H., PANG, W. and WONG, C. Methodology for monitoring supply chain performance: a fuzzy logic approach. Logistics Information Management, 15 (4): 271 - 280, 2002.

LEHTINEN, J. and AHOLA, T. Is performance measurement suitable for an extended enterprise?. International Journal of Operations \& Production Management, 30 (2): 181-204, 2010. 
MAMDANI, E.H. and ASSILIAN, S. An experiment in linguistic synthesis with a fuzzy logic controller. International Journal of ManMachine Studies, 7(1): 1-13, 1975.

LING, CH., CHIU, H. and TSENG, Y. Agility evaluation using fuzzy logic. International Journal of Production Economics, 101: 353 368, 2006.

OHDAR, R. and KUMAR, P. Performance measurement and evaluation of suppliers in supply chain: an evolutionary fuzzy-based approach. Journal of Manufacturing Technology Management, 15 (8): 723 - 734, 2004.

OLHAGER, J. Strategic positioning of the order penetration point. International Journal of Production Economics, 85 (3): 319-329, 2003.
SILVA, C., SOUSA, J. and RUNKLER, T. Optimization of logistic systems using fuzzy weighted aggregation. Fuzzy Sets and Systems, 158: 1947 - 1960, 2007.

SUGENO, M. and TAKAGI, T. Fuzzy identification of systems and its application to modeling and control. IEEE Trans. Syst. Man and Cybern., 15: 116-132, 1985.

WANG, W. A fuzzy linguistic computing approach to supplier evaluation. Applied Mathematical Modeling, 34: 3130 - 3141, 2010.

ZADEH, L. Fuzzy Sets and their applications to cognitive and decision processes. London: Academic Press, 1975. 